\title{
THE REGULATION OF ENGLISH MIDWIVES IN THE SIXTEENTH AND SEVENTEENTH CENTURIES
}

\author{
by \\ THOMAS R. FORBES
}

IN spite of the importance in past centuries of the services of the midwife, regulatory measures intended to ensure a reasonable level of skill and professional ethics came belatedly to western Europe. In England, basic regulation of midwives evolved in the sixteenth and seventeenth centuries. The following account is an attempt to outline this evolution.

The various bodies which eventually undertook to control the practice of the midwife seem to have concerned themselves more with her character than with her professional ability. Such concern was not unjustified. Evidence exists, for example, that some midwives were involved in witchcraft. ${ }^{1}$ There were other flaws. Aveling, in his excellent English Midwives, ${ }^{2}$ calls attention to the comments of Richard Jonas. In the latter's introduction to The Byrthe of Mankynde, his I 540 translation of Roesslin's work on midwifery, Jonas remarks:

for as touchynge mydwyfes/ as there be many of them ryght expert/ diligēt/ wyse/ circumspecte/ and tender aboute suche busynesse: so be there agayne manye mo [more] full undyscreate/ unreasonable/ chorleshe/ farre to seke in suche thynges/ the whiche sholde chieflye helpe and socoure the good women in theyr most paynefull labor and thronges [distress]. Throughe whose rudenesse [and] rasshenesse onely I doubte not/ but that a greate nomber are caste awaye and destroyed (the more petye). ${ }^{3}$

Some provision had been available for lying-in women in fifteenth-century hospitals and monasteries, but this appears to have ended with the dissolution of the religious houses under the Reformation. ${ }^{4}$ Deliveries occurred in private homes. Medical men seldom attended. The professional standards of the midwives were often deplorable and, indeed, could scarcely be said to exist. ${ }^{5}$ Andrew Boorde commented in 1547 that 'Yf it do come of evyl orderynge af a woman whan that she is delivered, it muste come of an unexpert midwife.' ${ }^{6}$ If the latter could be properly instructed, he says, 'there shulde not be halfe so many women myscary, nor so many children perished in every place in Englaunde as there be'. Willughby explained in 1670 that he had written his Observations in Midwifery in English because

few of our midwives bee learned in severall languages. For I have been with some, that could not read; with severall, that could not write; with many, that understood very little of practice, \& for such as these bee, it would no do good to speak to them of anatomizing of the womb, or to tell them of the learned workes of Mercatus, or Senertus, or Spigelius. ${ }^{7}$

Elizabeth Cellier (or Celleor), a remarkable member of the profession who was not only literate but outspoken, stated in a royal petition in 1687 :

That within the space of twenty years last past, above six-thousand women have died in childbed, more than thirteen-thousand children have been abortive and about five-thousand 


\section{Thomas R. Forbes}

chrysome infants [those in their first month of life] have been buried within the weekly bills of mortality; above two-thirds of which, amounting to sixteen thousand souls, have in all probability perished, for want of due skill and care, in those women who practice the art of midwifery. ${ }^{8}$

Copeman ${ }^{9}$ regards the appalling maternal and infant mortality in Tudor England as a major factor in preventing a population increase at a time when the birth-rate was high.

The Church was concerned about the practice of midwifery. Humanitarian considerations were not overlooked, but the overriding issue seems at first to have been the proper baptism of the infant. If the priest were not at hand, then the newborn child must be taken to him, even if a journey were necessary. Should it appear that the baby might die before the priest could perform the baptism, the midwife was obliged to conduct the rite, and it was of course essential that she do so correctly. At stake was the infant's very soul. ${ }^{10}$ Death before baptism meant that it must rest forever in limbo. There was also the possibility that an unsuspected witch-midwife might consign to her master the Devil the soul of the unbaptized child. ${ }^{1}$

The laws of the land provided severe penalties for persons convicted of witchcraft, this crime under James I becoming a felony. However, The Statutes of the Realm from the time of Magna Carta to the end of the reign of Queen Anne in 1714 do not mention midwives in this or any other connection. ${ }^{11,}{ }^{12}$ It would thus appear that during this period the Crown did not specifically attempt the regulation of midwifery. This may be another reason why the Church took the initiative.

The requirement that the midwife must if necessary perform the baptism was explicit in ecclesiastical law; ${ }^{1,13,14,15,16}$ in the Catholic faith she may do so to this day. ${ }^{17}$ Bishop Rowland Lee's Injunction for Coventry and Lichfield, dated about 1537, said that 'the midwife may use it [baptism] in time of necessity; commanding the women when the time of birth draweth near, to have at all seasons a vessel of clean water for the same purpose'. Other clerics of the period gave similar instructions. ${ }^{18}$ The Reformation brought at least one edict, in I577, 'that no midwifes, nor any other women, be suffred to minister babtisme',19 but Burn ${ }^{13}$ quotes parish records which indicate that the practice continued:

Oct. 12, 1591, Margarett, $D^{r}$ of Walter Henningham, de Pypehall, baptized by the mydwyfe, and as yett not broughte to $y^{e}$ Churche to be there examyned and testified by them that were there present.

The seventh day of August was buryed Jone Newman, the daught. of Robert Newman, domi baptizata erat p. obstetricem, 1583 .

Evidence for baptism by the midwife goes back to 1303, when Robert Mannyng of Brunne wrote, 'For every man bothe hyghe and loghe/The poyntes of bapteme owet to knowe.' He detailed the correct procedure, then added that midwives must understand it thoroughly. There followed the tale of a midwife who 'loste a chylde bothe soule and lyfe' because she used the wrong words. When the priest discovered her error, 'She was commaundede she shulde no 


\section{The Regulation of English Midwives in the Sixteenth and Seventeenth Centuries}

more/Come eftesones where chyldryn were bore'20 - an early case of clerical regulation of midwifery.

Similar admonitions were included by John Myrc, an English canon, about $145^{\circ}$ in his Instructions for Parish Priests. In specifying the midwife's duties in an obstetrical emergency, he lays down, possibly for the first time in England, some definite rules of professional conduct and the indications for Gaesarean section:

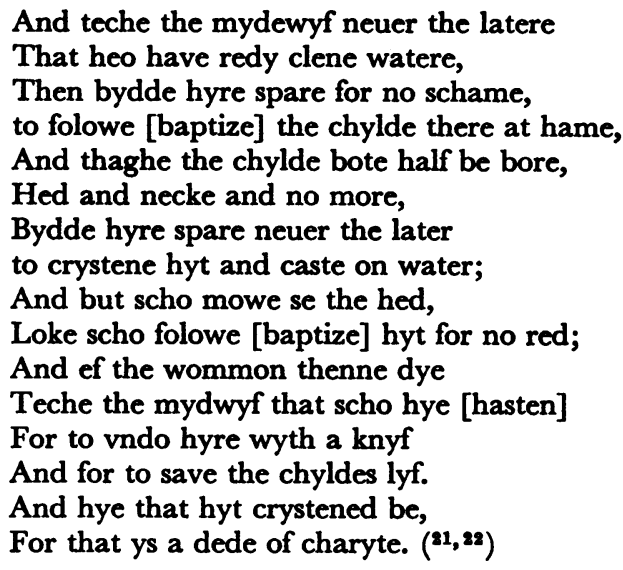

In 1512, under Henry VIII, an Act was passed which permitted representatives of the Church to grant licences for the practice of medicine and surgery to persons who had first been examined by the Bishop of London or the Dean of St. Paul's. ${ }^{23}, 24,25,26$ It seems likely that ecclesiastical licensing of qualified

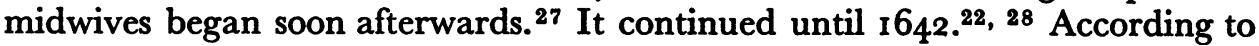
Elizabeth Cellier, Bishop Bonner (1500?-1569?) issued the first midwife's licence. ${ }^{29}$ 'In my tyme', suggested Andrew Boorde in 1547,

every midwife shuld be presented with honest women of great gravitie to the Byshoppe, and that they shulde testify for her that they do present shoulde be a sadde woman wise and discrete, havynge experience, and worthy to have ye office of a midwife. Than the Byshoppe with ye counsell of a doctor of phisicke ought to examin her, and to instruct her in that thinge that she is ignoraunt. ...

Several steps were necessary before the midwife's licence was issued. First, it was expected that she had acquired at least a degree of professional competence and had received proper instruction in the form of baptism. She then underwent examination as to her character and skill.13, 30 Before one Eleanor Peade was licensed on 26 August 1567 , she was questioned by Matthew, Archbishop of Canterbury, as to her knowledge of midwifery. She was also separately examined in this subject by eight women, presumably experienced midwives. ${ }^{31}$

A fascinating Book of Oaths of office for many kinds of officials, high and low, which was issued in 1649 includes a lengthy 'Oath that is to be ministred to a Mid-wife by the Bishop or his Chancellor of the Diocese, when she is licensed to exercise that Office of a Midwife.' The latter, says the oath, shall help rich and poor alike. She shall insist that the mother name the true father. The child must not be murdered, maimed, or exposed to avoidable peril. The midwife shall not 


\section{Thomas $R$. Forbes}

use witchcraft, charms, sorcery, unlawful prayers, or abortifacients, shall not demand an unusual fee, arrange for a secret delivery, disclose professional confidences, or permit the secret or improper burial of a stillborn infant. Unprofessional acts of other midwives and the practice of midwifery without a licence must be reported to the Bishop. Finally, the midwife must not permit baptism except as 'appointed by the Lawes of the Church of Englande'. ${ }^{32}$

The Norwich Diocese Book and records at Somerset House note the issuing of numerous licences. Examples read, in translation: 'Wells, Mary, 26 September [1662]. License to Mary Wells, midwife, wife of Thomas Wells of the Parish of Bletchingly.' 'Taylor, Jane. 9 April 1663. A license was granted to her as midwife in the parish of St. Olaf, Southwark. ${ }^{23,26,33}$ There are records of midwives being licensed by the Kirk Session of Perth in $16 \mathrm{II}_{1}{ }^{22},{ }^{34}$ by the Register of St. Finn Barrs Cathedral, Cork, in 1685 and $1686,{ }^{34 a}$ and by the King and Queen's College of Physicians in Ireland in $1696 .{ }^{35}$

No record has been found of the texts of sixteenth-century midwives' licences. Mention will be made later of some seventeenth-century licences.

Information is scanty regarding the amount of the fee for the licence. It is recorded that the wife of William Silke, surgeon, paid $18 s .6 d$. in 1662 for her licence as midwife; her husband's licence cost $135 .{ }^{27}$ Fees for midwives' licences were is or $2 s$. in $1706,{ }^{23,}{ }^{26}{ }_{1} 7 s .6 d$. between 1709 and $1719,{ }^{36} 8$ guineas in $17 \mathrm{I} 4$, $3^{s .} 4^{d}$. in 1719 , and $f_{10}$ in $173^{8.27}$ Fees for the services of the midwife also varied greatly. In $15586 \mathrm{~s}$. $8 \mathrm{~d}$. was paid to a midwife who travelled from Somersetshire to London for a confinement; ${ }^{2}$ 1 $2 d$. went to a rural midwife in 1610. A record for January 1612 notes: 'given to the midwiffe which helpe a cowe that could not calve $\mathrm{ij}^{\mathrm{s}} \mathrm{vj}^{\mathrm{d}}{ }^{37}{ }^{37}$ Fees for delivery in a town were higher than they were in the country and were also, sometimes, adjusted to the financial circumstances of the patient. Alice Dennis, the midwife who twice delivered Queen Anne, received $£ 100$ on each occasion. ${ }^{2}$ By comparison, the average fee for the services of an English physician in the latter part of the seventeenth century, according to Garrison, was about ros. ${ }^{5}$

It was the custom for a bishop to make periodic visits of inspection at the churches in his diocese. During such visitations he inquired not only into the spiritual well-being of his flock and the physical condition of the church building but granted an occasional licence, collected fees for licences already in force, and issued numerous instructions to the clergy and churchwardens. Richard Barnes, Bishop of Durham, left the record of 'Certeyne Monicions and Iniunctions given ... on Tewesdaie the first daie of October $1577 \ldots$. . Item 8 read, in part,

And we charge and commaunde yow duly, from tyme to tyme, to present the names and surnames of all suche women as shall taike in hande, or enterprice, to babtize, or at the childes birthe use supersticious ceremonyes, orizons, charmes, or develishe rytes or sorceries.10

The Visitation Articles of Bishop Edmund Bonner asked, among other things,

114. Whether there be any woman that doth occupy or exercise the office and room of a midwife, before she be examined and admitted by the bishop, or ordinary of this diocese, or this 


\section{The Regulation of English Midwives in the Sixteenth and Seventeenth Centuries}

chancellor or commissary, having sufficient authority, except in time of extreme necessity when the presence of the midwife cannot be had?

115. Whether such as hath heretofore been allowed and admitted to the said room and office of a midwife, be Catholic and faithful, discreet and sober, diligent and ready to help every woman travailing of child, as well the rich as the poor?38

The inquiries of other bishops were similar. ${ }^{18,38,39,40,41}$

Women practising midwifery without a licence could be brought to trial in a spiritual court and be fined or otherwise punished, ${ }^{26}$ although the jurisdiction of the court in regard to this offence was questioned on at least one occasion. ${ }^{13,22,42}$ There are a good many records of 'presentments' to the ecclesiastical officers of women who had practised midwifery improperly or without a licence. Thus the fabric rolls of York Minster for the period between 1362 and I550 (translation):

Driffield parva. ... Agnes Marshall, alias Saunder, of Emeswell, exercises the office of midwife without having either experience or knowledge of midwifery; moreover, she uses incantations.

...

Alne. . . . Item, Agnes Hobson of Alne administers love potions or apothecaries' potions of her own preparation, wherewith she destroys the foetus in the womb and even the mother, and she has given the said potions to very many women. She has made expiation 2 July.t3

From the Bampton churchwardens' presentments for I69I: 'We do present Elizabeth Harrison for acting as a midwife without a licence, to the prejudice of several persons.' 44

For the archdeaconry of Buckingham a whole series of presentments in 1662 has been set down. Brinkworth, the editor of these important transcripts, gives the clues for interpretation of the Latin abbreviations:

(Deanery of Burnham) p. the wife of John Church, midwife without supra ['approbacion or license', previously mentioned] i 7 Oct. 62: comp. et iurata ad exequendum officium obstetricis etc. [Presentment: the wife of John Church, midwife without sanction or licence. She appeared and took the oath to practise as a midwife, etc.]

Chesham. ... One goodwife Warde, a midwife. 17 Oct. 62: qu. etc. pco. comp. et iurata ad exequendum officium obstetricis. [Added in margin of original] dimittitur. [ 17 Oct. 1662 was sought, etc. Public proclamation having been made, she appeared and was sworn for exercise of the office of midwife. Case dismissed.]

In Turfield Joane Munday was presented on 4 December 1662 for practising midwifery '(for ought wee knowe) without a licence'. Jane, wife of John Drewce of Aylesbury, was presented for the same offence on 24 September 1662, was cited on ro October, failed to appear, and was excommunicated. This appears to have been a not unusual penalty. The names of a good many midwives are followed by a date and the terse notation 'c., pco., non comp., ex.'-citata, praeconizatio facta, non comparuit, excommunicatur (having been cited and public proclamation having been made, she did not appear, and is excommunicated). ${ }^{39}$ In the London County Record Office are lists of schoolteachers, surgeons, and midwives who were presented at the Consistory Court of London for violations. A great many of the errant midwives were either excommunicated or fined.

An amusing letter was written on 2 October 1675 by a clergyman, Benjamin Younge, to Dr. Thomas Exton, Vicar General to Humphrey, Bishop of London. 


\section{Thomas $R$. Forbes}

The letter, addressed to Exton at his lodgings in Doctors' Commons and now in the licence collection at the Guildhall Library, concerns

An Excomunication from yor Officer against two Midwifes practicing in my Parish without Licēncēs [licenes]. I presumed to forber denouncing of it till I had dealt with them to submit to ye authority of ye Court and to take out Licenenes of practice. Accordingly the barer hereof Dennys Younge ... hath so far been ruled by me, as to come to you to crave license of practice. Shee is a woman skillful in that way as hath been often approved, \& ye very citation grants: but her skill hath been most comonly made use of by ye poorer people from whom she received very little or no advantage, which made me bold the last year to sollicit your favor to her, when the like excō̄unication came to me against her, which yō were pleased to grant me. ... I humbly beg ye favor of you, yf shee may be dispatcht with speed, \& at as cheap a rate as may be, because her circumstances are but ordinary, \& her practice inconsiderable. . . I am willing to think that this is ye most acceptable way of executing your orders, which may be done upon most people but ye Quakers who are stubborn and refractory. Other persons will be likely to submit more easily when they shall hear yt. They may be used mildly and gently. This Sir with my most humble Duty to my Reverend Diocesan, my faithfull respects and obedience to your selfe, is all from

Sr Yor most humble Servt

Ben: Younge

It is cheering to record that Dr. Exton granted the licence on 4 October 1675 .

In 1616 , or perhaps a little earlier, the Chamberlen family became involved with the midwives. The story has been told in detail by Aveling ${ }^{2,45}$ and others, and will only be summarized here. William Chamberlen the obstetrician had two sons, both named Peter, who took up their father's profession. In 1616 the midwives of the City of London petitioned the King for permission to incorporate into a society. The petition, which had the support of both Peter Chamberlens, pointed out the urgent need for better training of midwives through 'lectures upon Anatomies and other Aucthorety for orders and helpes for instruccon and increase of skill amongst them .... The College of Physicians, to whom the petition was referred, agreed that reforms were greatly to be desired but opposed the formation of a corporation. The College suggested that

before the midwives were licensed by the Bisshopp or his Chauncellour they be first examined and approved by the President of the College of the Phisitions and two or iij of the gravest of that Society such as the President shall nominate. And likewise for abuses and disorders by any of them comytted thay may be censured of the Colledge accordinge as ys used in all other evell practizers in Phissick. And for the bettringe of their skill and knowledge the College maketh offer to dispute such grave and learned men as shall allwaies be ready to resolve all their doubts and instruct them in what they desire concerninge Midwiferye and once or twice in the yeare to make privat dissections and Annattomyes to the use of their whole Company. . . ${ }^{45,46}$

Peter Chamberlen III, son of Peter Chamberlen the Younger, was a Fellow of the College of Physicians and a successful obstetrician. He attempted himself to organize the midwives and, according to an angry contemporary account, to secure sole authority to instruct, approve, and license them. His proposal so disturbed the midwives that they petitioned the King and the College of Physicians to prevent Chamberlen from being allowed to gain control over the profession. The College took the side of the midwives, and Chamberlen's project failed. ${ }^{47}$ In 1634 the midwives again petitioned, this time for permission to 


\section{The Regulation of English Midwives in the Sixteenth and Seventeenth Centuries}

incorporate. The Chamberlen family had continued its support, but effective opposition came from the organized medical profession, and the petition was denied. ${ }^{45,} 46$

The original recommendation of the College of Physicians, however, was implemented in 1642 , when authority to license midwives was transferred from the bishops to the physicians and surgeons at Surgeons' Hall. This was an important advance. A good many years later, Elizabeth Cellier set down her version of the ensuing period:

... the Physicians and Chirurgions contending about it [the role of the midwife at a delivery], it was adjudged a Chyrurgical Operation, and the Midwives were Licensed at Chirurgion's Hall, but not till they had passed three Examinations, before six skilful Midwives, and as many Chirurgions expert in the Art of Midwifery. Thus it continued until the Act of Uniformity passed, which sent the Midwives back to Doctors Commons, where they pay their money, (take an Oath which is impossible for them to keep) and return home as skilful as they went thither.

I make no reflection on those learned Gentlemen the Licensers, but refer the curious for their further satisfaction, to the Yearly Bills of Mortality, from [16]42 to [16]62: ... they will find there did not then happen the eight [sic] part of the Casualties, either to Women or Children, as do now. 29

Mrs. Cellier's testimony to the value of licensing only those midwives who could pass a careful professional examination appeared in the preamble to a petition of her own to James II. In this remarkable document, submitted in June 1687 , she proposed the founding of a royal hospital, to be maintained by a corporation of $\mathrm{I}, 000$ skilled, dues-paying midwives. Unfortunately, as Aveling points out, it appears that the scheme was far from practical and that it would have been operated in large measure for the financial benefit of Mrs. Cellier. ${ }^{2}$ It is regrettable, however, that the plan for professional instruction of midwives was not implemented.

As it was, licensing went 'back to Doctors Commons', i.e., to routine ecclesiastical regulation. There was no further mention of the all-important qualifying examination, and even the oath of office, if one is to believe the vehement Mrs. Cellier, could not be kept.

The earliest midwives' licences which I have found date from this period. The Guildhall Library has a fine collection of original documents issued to residents of various London parishes, and there are more in the library of Lambeth Palace. Mrs. Cellier was in error when she said that licensing by the Church was resumed in 1662 ; perhaps she had forgotten the correct day by the time she wrote her account in 1687 . Episcopal licences in the Guildhall collection date from January 166o. An unusually detailed document, issued 16 November $166 \mathrm{I}$, reads in part:

These are to certifie the honoble the Consistory court of the Lord Bishop of London held by the right worpll Doctor Richard Chaworth his Chancellor in the Hall of Doctors Commons that Judith Newman wife of William Newman of the parish of Allhallows the less hath lived in the said parish thirty yeares and upwards during which tyme shee hath demeaned herself honestly and in love and charity with her neighbours, And that shee is in our judgments able and sufficient for the Office and ffunction of a Midwife which shee hath many yeares past been exercised in, And therefore we Recomend her unto yr honor for the exercise of such an office and ffunction. 


\section{Thomas R. Forbes}

Appended are the signatures of the curate, two churchwardens, two 'common counsellmen', and one midwife, and the mark of another. There is also a list of six women, presumably delivered by Judith Newman. Under the list is the statement approbat et Furat testes et obstetrix [sic] pro Mr. Foh: Williams Surrogat in Loco Registri 16 Novemb. $166 \mathrm{I}$ and, in another hand, 'practised 15 or 16 yeares'.

The Guildhall licences vary somewhat in form. In general, there is a statement, usually in a clear hand, that the bearer, a resident of a specified parish of London, is a woman of honest life and 'conversation' (demeanour). Frequently it is added that she is a member of, or conformable to, the Church of England. There may also be an assertion that she is an experienced or competent midwife. The testimonial certificate is signed by the minister, rector, or curate of the parish and often by two churchwardens. Usually the names of three to six or eight other men and women also are listed as witnesses. The names of the parishes of residence and the occupations of the witnesses or their husbands (instrument maker, cordwainer, tailor, upholsterer, etc.) may be given. Occasionally a witness is identified as a midwife. Since the names of the witnesses are all appended in the same handwriting rather than as actual signatures, it seems likely that illiteracy was not unusual. Often included is a separate list of the names of six women, their husbands' names, and their parishes. Before the name of each woman appears the numeral I, 2, or 3. Presumably this is a list of women delivered by the applicant and the number of confinements involved.

At the bottom of the parchment is the licence proper. It is a statement in Latin to the effect that on a specified date the applicant appeared before, and was approved and sworn by, a person who signs the statement as a surrogate, or deputy of the bishop or his chancellor. Often the witnesses also were sworn. The legal formula varies, even as written by the same surrogate. It might read Margarita Corney jurat 12 Nov. I66I coram $M^{\text {ro }}$ [Magistro] $70:$ Wms Sur..$^{10}$ [Williams Surrogato] or 22 Martii 1675 Anna Dobson et mulieres pecia [paroecia, parish] jurat[a] cor[am] me Tho: Exton. Sometimes ffiat Licentia or Concedatur Licentia is added.

To modern eyes the striking feature of these documents is that the principal, and sometimes the only, qualification of the midwife which was mentioned was that she was a person of good character. If there was any reference to her professional competence, it was usually to the number of years that she had functioned as a midwife, although laymen sometimes testified to her skill. Thus, like her training, the licensing of the midwife was grossly inadequate by modern standards. Nevertheless, there did develop during the sixteenth and seventeenth centuries a procedure for admitting to the licensed practice of midwifery only those women who were respected in their parishes for their morality, discretion, and sobriety and for their experience in their craft. On the long path to effective regulation, it was not a bad beginning. 
The Regulation of English Midwives in the Sixteenth and Seventeenth Centuries

\section{ACKNOWLEDGMENTS}

This research was supported in part by a grant from Ciba Pharmaceutical Products, Inc.

The author is indebted to Mr. A. H. Hall, Librarian, and Mr. A. E. J. Hollaender, Archivist, for kindly making the resources of the Guildhall Library available to him.

\section{REFERENCES}

1. For Bes, T. R., Midwifery and witchcraft, 7. Hist. Med., 1962, 17, 264-83.

2. Aveling, J. H., English Midwives; Their History and Prospects, London, Churchill, 1872.

3. [Rokssin, Eucharius], The Byrthe of Mankynde, Newly Translated out of Laten into Englysshe [by Richard Jonas], London, T. R[aynald], I540.

4. Penchey, G. G., Installation of a midwife, Notes and Queries, 1900, 9th ser., 6, $177,438$.

5. Garrison, F. H., An Introduction to the History of Medicine, Philadelphia and London, Saunders, 1929.

6. [BOORDE, ANDREW], The Breuyary of Helthe, London, W. Myddelton, 1547.

7. Willughby, Percival, Observations in Midwifery, London, MS, in Library of Royal Society of Medicine[circa 1670$]$.

8. Oldys, William, The Harleian Miscellany ...., London, White, 1809.

9. Copeman, W. S. C., Doctors and Disease in Tudor Times, London, Dawsons, 1960.

10. [Hardourn, Jean], Acta Conciliorum et Epistolae Decretales, ac Constitutiones Summorum Pontificum. Tomus Nonus. Ab Anno MCCCCXXXVIII ad Annum $M D X L I X$, Paris, Typographia Regia, 1714.

I I. ANON., The Statutes of the Realm, printed by Command of His Majesty King George the Third, [no place, no publ.] 1817.

12. Anon., Ancient Laws and Institutes of England ...., [no place, no publ.] 1840.

13. Burn, J. S., Ecclesiastical Law, 6th ed., London, A. Strahan, 1797.

14. - Registrum Ecclesiae Parochialis, The History of Parish Registers in England ...., London, E. Suter, 1829.

I5. Burnet, Gilbert, The History of the Reformation, Oxford, Clarendon Press, I865, vol. $\mathrm{II}$.

16. VAN EsPen, D. Z. B., Jus ecclesiasticum ..., Venice, [no publ.] 1784 .

17. Gasparri, Pietro, Codex Iuris Canonici ...., Vatican, 1933.

18. FRERE, W. H. and KENNEDY, W. M., Visitation Articles and Injunctions of the Period of the Reformation, Alcuin Club Collections, London, Longmans, Green, I9I0, vol. Xv.

19. RAINE, J., ed., The Injunctions and Other Ecclesiastical Proceedings of Richard Barmes, Bishop of Durham, from 1575 to 1587 , Publications of Surtees Soc., Durham, G. Andrews, 1850, 22, 13-23.

20. [Mannyng, Robert], Roberd of Brunne's Handlyng Synne (Written A.D. I303) ... ., ed. by F. J. Furnivall, London, J. B. Nichols, 1862, lines 9592-9649.

21. Myrc, Jонn, Instruction for Parish Priests, ed. by Edward Peacock, London, Trübner, 1868 , lines 87-102.

22. Atrinson, S. B., The Office of Midwife (in England and Wales) under the Midwives Act, 1902 (2 Edw. VII, c. 17) . . ., London, Baillière, Tindall \& Cox, 1907. 


\section{Thomas R. Forbes}

23. Barnes, Henry, On the Bishop's licence, Trans. Cumberland and Westmorland Antiquarian and Archaeol. Soc., I903, n.s. 3, 59-69.

24. Peachey, G. C., Note upon the provision for lying-in women in London up to the middle of the eighteenth century, Proc. roy. Soc. Med., 1924, 17, 72-5.

25. Penny, Frank, Installation of a midwife, Notes and Queries, 1900, 9th ser., 6, 336-7.

26. Williams, Gharles, Installation of a midwife, Notes and Queries, 19oi, 9th ser., 7, 3i-2.

27. Hurd-MeAd, K. C., A History of Women in Medicine, Haddam, Conn., Haddam Press, 1938.

28. ANON., Celebrated midwives of the I 1 th and beginning of the 18 th centuries: with a short account of the present position of midwives, St. Thos. Hosp. Gaz., $1895,5,33-6$.

29. Gemleor, Elizabeth, To Dr. - an Answer to His Queries, Concerning the Colledg of Midwives, London, [no publ.] [1687].

30. Blencowe, R. W., Extracts from the parish registers and other parochial documents of East Sussex, Sussex Archaeol. Collections, 1851, 4, 243-90.

31. Thompson, E. M. and Frere, W. H., Registrum Matthei Parker, Diocesis Cantuariensis, A.D. 1559-1575, Oxford, University Press, 1928.

32. Anon., The Book of Oaths, and the Severall Forms Thereof, Both Ancient and Modern ..., London, M. Walbancke, 1649.

33. BAx, A. R., Marriage and other licences in the Commissary Court of Surrey, Surrey Archaeol. Collections, 1893, 11, 204-43.

34. Wallace James, J. G., Installation of a midwife, Notes and Queries, 1900, 9th ser., 6, 177 .

34a.R. C., Midwives, Notes and Queries, I86r, 2nd ser., II, 59.

35. Ringland, John, Annals of Midwifery in Ireland ..., Dublin, J. Falconer, 1870.

36. Kerslake, Thomas, Midwives licensed, Notes and Queries, 1850, Ist ser., 2, 499.

37. Harland, John, The house and farm accounts of the Shuttleworths of Gawthorpe Hall, in the County of Lancaster . . ., Chetham Soc., Remains Histor. and Lit., 1856, 35, 189, 198.

38. Frere, W. H., ed. Visitation Articles and Injunctions of the Period of the Reformation, Alcuin Club Collections, London, Longmans, Green, I9ro, vol. xvi.

39. BRINKWORTH, E. R. C., Episcopal Visitation Book for the Archdeaconry of Buckingham, 1662, Buckinghamshire Record Soc., Bedford, Sidney Press, 1947, vol. vIr.

40. Cardweli, Edward, Documentary Annals of the Reformed Church of England ..., Oxford, University Press, 1844 .

4I. E.H.A., Midwives licensed, Notes and Queries, 185I, Ist ser., 3, 29.

42. Godolphin, John, Reportorium Canonicum ..., London, C. Wilkinson, 1687.

43. Raine, J., ed., The Fabric Rolls of York Minster . . ., Publication of Surtees Soc., Durham, G. Andrews, 1850, 22, 13 -23.

44. M.N., Installation of a midwife, Notes and Queries, 1900, 9th ser., 6, 274.

45. Avening, J. H., The Chamberlens and the Midwifery Forceps ..., London, Churchill, 1882.

46. SPencer, H. R., The History of British Midwifery from 1650 to 1800 , London, J. Bale, Sons and Danielsson, 1927.

47. Goodali, Chardes, An Historical Account of the College's Proceedings against Empiricks and Unlicensed Practicers, etc., London, M. Flesher, r684. 